\title{
Molecular epidemiology of Rotavirus causing diarrhea among children less than five years of age visiting national level children hospitals, Nepal
}

Subhash Dhital ${ }^{1 *}$ (D, Jeevan Bahadur Sherchand ${ }^{2}$, Bharat Mani Pokhrel², Keshab Parajuli², Niranjan Shah², Shyam Kumar Mishra², Sangita Sharma², Hari Prasad Kattel², Sundar Khadka', Sulochana Khatiwada², Narayan Parajuli ${ }^{4}$ and Basistha Rijal ${ }^{2}$

\begin{abstract}
Background: Rotaviruses are the major cause of diarrhea among the infants and young children all over the world causing over 500,000 deaths and 2.4 million hospitalizations each year. In Nepal Rotavirus infection positivity rates ranges from 17.0 to $39.0 \%$ among children less than 5 years. However, little is known about the molecular genotypes of Rotavirus prevailing. The objective of this study was to estimate the burden of Rotavirus gastroenteritis and determine the genotypes of Rotavirus among children less than 5 years.

Methods: The cross sectional study was conducted from January to November 2014 among children less than 5 years old visiting Kanti Children's Hospital and Tribhuvan University Teaching Hospital.

Rotavirus antigen detection was performed by Enzyme Linked Immunosorbent Assay (ELISA) using ProSpecT Rotavirus Microplate Assay. Among the Rotavirus antigen positive samples, 59 samples were used for Rotavirus RNA extraction. Multiplex PCR was performed to identify G type comprising G1-G4, G8-G10 and G12 and P type comprising P[4], P[6], $\mathrm{P}[8], \mathrm{P}[9], \mathrm{P}[10]$, and $\mathrm{P}[11]$.

Results: A total of 717 diarrheal stool samples were collected from patients ranging from 10 days to 59 months of age. Rotavirus antigen positive was found among ( $N=164) 22.9 \%$ of patients. The highest number of the diarrhea was seen in January. Molecular analysis of Rotavirus genotypes revealed that the predominant G-Type was G12 (36\%) followed by G9 (31\%), G1 (21\%), G2 (8.6\%). The predominant P- type was P6 (32.8\%) followed by P8 (31\%), P10 (14.8\%), P4 (14.8\%). A total of seven G/P type combinations were identified the most common being G12P [6] (35.8\%), G1P [8] (15.1\%), G9P [8] (15. $1 \%)$.
\end{abstract}

Conclusion: Rotavirus diarrhea is, mostly affecting children from 7 to 24 months in Nepal, mostly occurring in winter. The circulating genotypes in the country are found to be primarily unusual genotypes and predominance of G12P[6]. It is recommended to conduct genotyping of Rotavirus on large samples before starting vaccination in the country.

Keywords: Rotavirus, Diarrhea, Nepal

* Correspondence: dhital.subhash@iom.edu.np

${ }^{1}$ National Public Health Laboratory, HIV Reference Unit, Kathmandu, Nepal

Full list of author information is available at the end of the article

(c) The Author(s). 2017 Open Access This article is distributed under the terms of the Creative Commons Attribution 4.0 International License (http://creativecommons.org/licenses/by/4.0/), which permits unrestricted use, distribution, and reproduction in any medium, provided you give appropriate credit to the original author(s) and the source, provide a link to the Creative Commons license, and indicate if changes were made. The Creative Commons Public Domain Dedication waiver (http://creativecommons.org/publicdomain/zero/1.0/) applies to the data made available in this article, unless otherwise stated. 


\section{Background}

Rotaviruses are non-enveloped, double stranded RNA viruses with 11 gene segments under Reoviridae family having seven major groups (A-G) [1]. Group A Rotaviruses are the major causes of diarrhea among the infants and young children all over the world [2] causing over 500,000 deaths and 2.4 million hospitalizations each year [3]. The virus is composed of three concentric layers; the outermost shell contains VP7 or G protein and VP4 or P protein, which are able to produce neutralizing antibodies during infection of a host [1]. Such neutralizing antibodies are the basis of dual classification of group A rotaviruses into $G$ and $\mathrm{P}$ types. With the advent of molecular techniques (Reverse transcriptase, RT-PCR), classification into G and $P$ type on the basis of genes encoding the $G$ and $P$ proteins has become widely accepted standard technique [4].

Virtually every child around the globe experiences Rotavirus diarrhea by the age of 3-5 years [2]. The higher standards of living style, good hygiene and proper sanitation followed in developed countries are not merely sufficient to prevent Rotavirus diarrhea. Although the incidence of diarrhea is similar in developed and developing countries, the Rotavirus diarrhea differs characteristically between them, in developing countries the severity as well as mortality is very high, many strains occur at a time and disease occurs at early age [5]. In addition, in developing countries diarrhea results in a deadly cycle of malnourishment and diarrhea [6].

With no availability of antivirals, vaccines are hoped to prevent disease, reduce morbidity and mortality of the disease. World Health Organization (WHO) has recommended the inclusion of Rotavirus vaccination of infants into all national immunization programs [7]. Eighty four countries including 36 low income countries have introduced Rotavirus vaccination and global coverage is estimated to be $23 \%$. Although the efficacy of oral vaccines in developing countries, in presence of other enteric infections, was dubious; recent data shows vaccination was successful in substantially reducing severe diarrhea and/or rotavirus disease [8]. However, Rotavirus vaccination has not been included in national immunization program in Nepal. And studies on Rotavirus infection from 1999 to 2007 showed positivity rates ranging from 17.0 to $39.0 \%$ among children less than 5 years [9].

Globally, G1, G2, G3, and G4 constitute more than $88.5 \%$ of globally identified strains [5]. At odds with global scenario, the most frequently reported $G$ types included G12, G1, G2, G9 from Nepal [10-13]. The first description of G12 rotaviruses dates back to the 1990s from Philippines which were characterized serologically and by nucleotide sequencing as G12P[4]. Beginning in 2002, reports of the detection and increased prevalence of G12 strains have appeared from Asia (Thailand, India, Korea, Japan, Bangladesh, Nepal, and Saudi Arabia) and the America (the United States, Argentina, and Brazil) [14].

There are regional and geographical differences as well as difference over time in same region in strain distribution [7]. The enormous diversity of Rotavirus is mainly because of point mutations, genetic reassortment or introduction of animal viral strains to human beings [15]. Therefore, rotavirus surveillance is needed to monitor the prevalence and possible changes of the different $G$ and $P$ types circulating in the region.

The study was conducted to estimate the burden of Rotavirus gastroenteritis as well as genotype of rotavirus among children less than 5 years of age visiting national level children hospitals, Kanti Children's Hospital and Tribhuvan University Teaching Hospital.

\section{Methods}

The cross sectional study was conducted from January to November 2014 among children less than 5 years of age visiting national level children hospitals, Kanti Children's Hospital and Tribhuvan University Teaching Hospital. These both hospitals are situated in Kathmandu city, capital of Nepal. These are among the largest hospitals of the country. Kanti Children's Hospital is only central/national pediatric hospital of the country.

Seven hundred seventeen single diarrheal stool specimens were collected from children with acute diarrhea who were referred to the observation ward and who were admitted to the hospital for not more than 3 days. The $10-20 \%$ suspensions of the specimens were made using phosphate buffered saline for antigen testing and genotyping in different vials and stored at $-20{ }^{\circ} \mathrm{C}$.

Stool samples were initially tested for group A Rotavirus antigen using ProSpecT Rotavirus enzyme immune assay (Oxoid Ltd., Basingstoke Hants, UK) and subsequently random 59 Rotavirus antigen positive samples were selected for RNA extraction using the commercial QIAamp Viral RNA Mini Kit (QIAGEN Inc). The tests were performed as specified by manufacturer.

\section{RT PCR}

The extracted dsRNA was converted to cDNA as described by Gouvea et al. [16]. The formed cDNA was used for subsequent PCR reactions.

\section{Typing by multiplex PCR \\ G-Typing}

The first round of G type PCR was targeted to gene segment 9. Amplification of the fragment was performed with primers, VP7-F (5'ATG TAT GGT ATT GAA TAT ACC AC3') and VP7-R (5'AAC TTG CCA CCA TTT TTT $3^{\prime}$ ) in a $50 \mu \mathrm{l}$ of a PCR mixture (5 U Taq DNA 
polymerase; $10 \mathrm{mM}$ each dNTP's; $50 \mathrm{mM} \mathrm{MgCl}_{2}$; 20 pmol of each primer; 10X buffer). The second round, a multiplex PCR was designed to identify the genotypes G1-G4, G8-G10 and G12 [12, 17].

\section{P-Typing}

The first round of P type PCR was targeted to gene segment 4. Amplification of fragment was performed with primers, VP4-F (5'TAT GCT CCA GTN AAT TGG3') and VP4-R (5'ATT GCA TTT CTT TCC ATA ATG 3') in a $50 \mu \mathrm{l}$ of a PCR mixture ( $5 \mathrm{U}$ Taq DNA polymerase; $10 \mathrm{mM}$ each dNTP's; $50 \mathrm{mM} \mathrm{MgCl}_{2} ; 20$ pmol of each primer; 10X buffer) The second round, a multiplex PCR was designed to identify the genotypes $\mathrm{P}[4], \mathrm{P}[6], \mathrm{P}[8]$, $\mathrm{P}[9], \mathrm{P}[10]$, and $\mathrm{P}[11]$ [18].

\section{Results}

Seven hundred and seventeen patients less than 5 years of age were enrolled in the study with age from 10 days to 59 months. The highest number of patients $(N=341)$ belonged to age group $0-12$ months followed by $(N=202)$ 13-24 months. In total there were 475 (66.2\%) males and 242(33.8\%) females. The dataset generated during the study are available in the data_diarrhea repository within the Additional file 1.

\section{Occurrence of Rotavirus diarrhea}

All samples were examined for Rotavirus using ELISA. The ELISA of Rotavirus antigen was found to be positive among $22.9 \%(N=164)$ of the isolates.

\section{Monthly occurrence of Rotavirus diarrhea}

The highest number of rotaviral diarrhea $(N=30)$ was seen in January followed by $(N=26)$ in February as shown in Fig. 1.

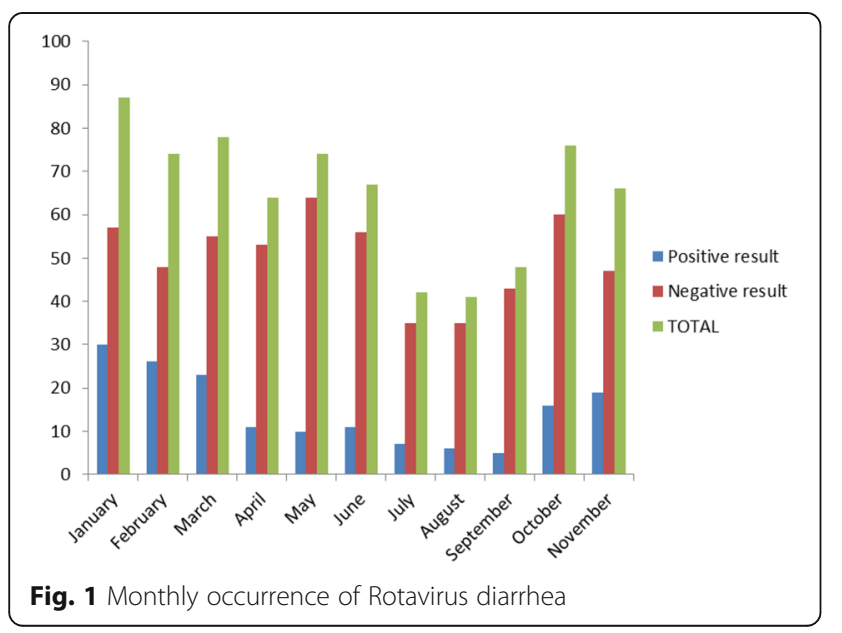

\section{Age wise distribution of Rotavirus ELISA result}

The highest number of Rotavirus positive diarrheal patients was detected on 0-12 month age group category which accounted $56.0 \%$ of total Rotavirus positive samples as shown in Table 1.

\section{Distribution of G-Type of Rotavirus}

Molecular analysis of Rotavirus genotypes revealed that the predominant G-Type was G12 $(n=21,36 \%)$ followed by G9 ( $n=18,31 \%), \mathrm{G} 1(n=11,21 \%), \mathrm{G} 2$ $(n=5,8.6 \%)$. Out of five G-types, G3 $(n=4)$ was least found genotype representing $3.4 \%$, while $1.8 \%$ was found to be untypable.

The genotype was determined according to the electrophoresis of the product which differed according to the basis base pairs as shown in Fig. 2 .

\section{Distribution of P-Type of Rotavirus}

Molecular analysis of Rotavirus genotypes revealed that the predominant P-type was P[6] $(n=19,32.8 \%)$ followed by P[8] ( $n=17,31 \%), \mathrm{P}[10]$ ( $n=1014.8 \%), \mathrm{P}[4]$ $(n=9,14.8 \%)$. Similarly, $6.6 \%$ of isolates were found to be untypable.

\section{Genotypic distribution of Rotavirus}

In total seven G/P type combinations were identified, including G12P[6] (35.8\%), G1P[8] (15.1\%), G9P[8] (15.1\%) which was the most commonly detected Rotavirus strain type, followed by G9P[4] (9.4\%), G2P[4] (7.5\%). (Table 2).

\section{Discussion}

The Rotavirus antigen positive was found among $22.9 \%$ of the isolates in the study similar to other studies in Nepal; $25.9 \%$ by Ansari [19] et al., 17\% by Uchida R [20] et al. and $33 \%$ by Sherchand et al. [13]. The incidence rate is comparable to the reports from India, Malaysia, Japan and Taiwan (20-25\%) but much lower than Thailand, Myanmar and Vietnam (38.1-56\%) [21]. These higher prevalence countries also relied on similar method of detection i.e. Enzyme immunoassay of Rotavirus antigen, the higher incidence rate in these countries is ascribed to low occurrence of other etiology (bacteria) of diarrhea, increased level of economic standards, proper water supply and good hygiene.

Table 1 Age wise distribution of Rotavirus ELISA result

\begin{tabular}{llll}
\hline $\begin{array}{l}\text { Age group } \\
\text { (months) }\end{array}$ & Positive Result & Negative Result & Total \\
\hline $0-12$ & $92(56.1 \%)$ & 249 & 341 \\
$13-24$ & $45(27.5 \%)$ & 157 & 202 \\
$25-36$ & $14(8.5 \%)$ & 69 & 83 \\
$37-48$ & $8(4.8 \%)$ & 43 & 51 \\
$49-60$ & $5(3.05 \%)$ & 35 & 40 \\
\hline
\end{tabular}




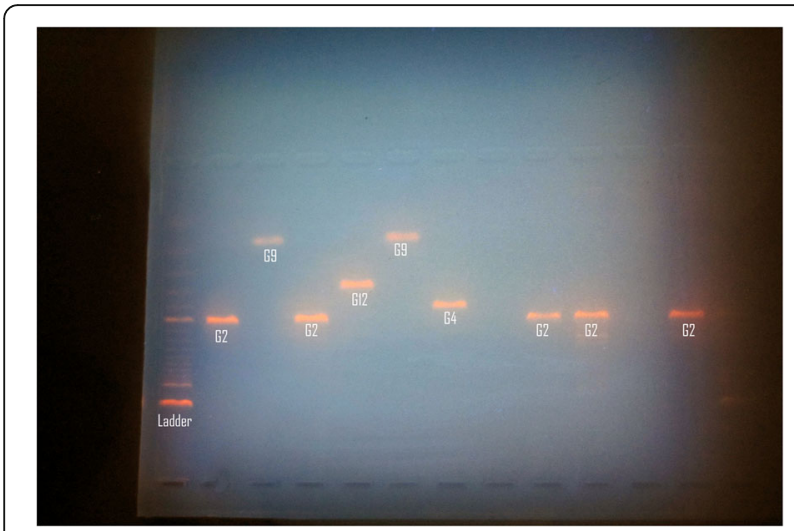

Fig. 2 Gel run of G-type PCR showing Ladder (Lane 1), G2(Lane2), G9(Lane3), G2(Lane4), G12(Lane5), G9(Lane6), G4(Lane7), UT(Lane8), G2(Lane09), G2(Lane10), Negative control(Lane 11), G2(Lane 12) from left to right.

In the study overriding Rotavirus infections was observed in 1 year's age group accounting $56.0 \%$ of total Rotavirus positive samples $(P$ value $=0.03,<0.5)$. In the group, most infections (34.2\% of total) occurred at the age of 7 to 12 months. And more than $80 \%$ of Rotavirus infections are found within the 2 years of age. Similarly, various studies have found that most of Rotavirus infections occur within 2 years of age, particularly after 7 months of age [19, 22-24]. Thus, vaccination at an early age can be beneficial to prevent majority of cases of diseases.

Researches have shown that infant below 4 months of age were initially protected to some extent by maternal antibodies against severe rotavirus diarrhea, and breast feeding as another independent factor preventing the

Table 2 Genotypic distribution of Rotavirus

\begin{tabular}{lll}
\hline Distribution of genotypes & & \\
\hline S.N & Genotype & Total \\
\hline 1. & G1P[8] & 8 \\
2. & G1P[10] & 2 \\
3. & G2P[4] & 4 \\
4. & G2P[10] & 1 \\
5. & G3P[10] & 2 \\
6. & G9P[4] & 5 \\
7. & G9P[8] & 8 \\
8. & G9P[10] & 2 \\
9. & G12P[6] & 19 \\
10. & G12P[8] & 1 \\
11. & G12P[10] & 1 \\
12. & MIXED & 4 \\
13. & PARTIAL & 5 \\
\hline
\end{tabular}

diarrhea, which can be a reason to have peak after 7 months [25, 26].

Rotavirus diarrhea is a disease of winter, recognized as a winter gastroenteritis and vomiting but seasonality may vary year to year [27]; in this study, peak in the number of RVGE cases was observed between January and March and marked the seasonal variation, with peaks occurring in cooler and drier months of the year. However, seasonal nature of Rotavirus is not universal, and in countries within $10^{\circ}$ of the equator, infection occurred year round. Similar type of seasonal variation has been reported by Uchida $\mathrm{R}$ et al. [20], Sherchand et al. [13], Sherchan et al. [28] from studies done in Nepal. Notably, in this study, the cases were found whole year round; in contrast Uchida et al. [20] found no cases in August and September and Sherchan [28] et al. did not find any case of Rotavirus diarrhea in July.

Molecular analysis of Rotavirus genotypes revealed that the predominant G type was G12 (36\%) followed by G9 (31\%), G1 (21\%) and G2 (8.6\%). The predominance of G 12 is in agreement with other studies as well, in a 3 year study by Sherchand et al. from November 2005 to October 2008 in Nepal, G12 was predominant in all 3 years, 2005-2006 (50\%), 2006-2007(29\%), and 20072008 (33.7\%) [29]. In comparison to previous studies in Nepal, there are subtle changes in the genotypes. In a study by Ansari et al. (2013), G 12 (56\%) was most predominant followed by G2, G1 and G9 [19]. However, in a study by Uchida et al. (2006) G1 was predominant, followed by G 12 and G2. In current scenario, G12 is being regularly reported in high frequencies from South East Asian countries-India, Bangladesh with considerable diversity suggesting Ganges region can be its origin from where it might have transmitted across the globe [30-32]. Remarkably, we have reported $31 \%$ of G9, higher percentage in comparison to previous studies in Nepal. G9 was first reported from Philadelphia and after 1990s it has been found with increased frequency worldwide, it has been reported from India, Brazil, Italy, the United States, Bangladesh, Malawi, the United Kingdom, France, and Australia [33, 34]. When the molecular study of Rotavirus begun from 2003 in Nepal by Uchida et al., in that first study G9 was not found, in subsequent studies by Sherchand et al. and Ansari et al. there were G9 genotypes occurrence comprising 2-6\% [19, 20, 28]. Alike kind of increase in G9 has also been observed in neighboring country India, from 2 to $10 \%$ in 2003-2007 to around $40 \%$ in 2013 [35]. The increment of G9 can be because of the escape recognition by immune system of Nepalese children where G 12 was predominant in previous years. In spite of all, emerging unusual G12 genotype continues to be a predominant in our context and circulating genotypes are within the cluster of G12, G9, G1, G2 and G3 [11-13, 19, 20, 28]. 
In this study the major P-type was $\mathrm{P}[6]$ (32.8\%) followed by $\mathrm{P}[8]$ (31\%), P[10] (14.8\%) and P[4] (14.8\%), previous studies also concordantly depicted either $\mathrm{P}[6]$ or $\mathrm{P}[8]$ to be the leading one $[11-13,19,20,28]$. $\mathrm{P}[6]$ has been commonly detected from symptomatic infections as major genotype nowadays, although previously, P[6] VP4 genotypes were detected from asymptomatic infections only [36-38]. In the study $\mathrm{P}[10]$ was found among less than one fourth of isolates in association with G1, G2, G3, G9 and G10, although P[10] was not reported before. The P-type $(\mathrm{P}[10])$ as a unusual serotype has also been reported from African countries like Cameroon, Ghana, Libya [39].

The most common genotype combination in this study is found to be G12P[6] (36\%) followed by G1P[8] (15.1\%), G9P[8] (15.1\%) G9P[4] (9.4\%), G2P[4] (7.5\%). Comparing the Rotavirus genotype result from Nepal in various studies, G12P[6] was found to be $12 \%$ in 2006 [20], 29\% in 2011 [28], $46.4 \%$ in 2013 [19] and 36\% in this study showing prevailing characteristics of G12 P[6]. Although globally 5 G-P combinations (G1P[8], G2P [4], $\mathrm{G} 3 \mathrm{P}[8]$, G4P [8]) and G9P[8]) is responsible for approximately $90 \%$ of all human rotavirus infections; the unusual serotypes of Rotavirus infections in our context is anticipated. It has been described that unusual $G$ and $\mathrm{P}$ combinations constitute more than $14 \%$ of reported rotavirus isolates from Asia, 27\% from Africa, 11\% from South America, 5\% from North America, 1.4\% from Europe, and 0.1\% from Australia [40]. Unlike developed countries where one or two genotypes predominate in a season [41], large number of genotype combinations along with unusual genotypes are comprehended in our study. Mixed Rotavirus infection was observed in $7.5 \%$. G $1 / G 12, P[4] / P[6]$ and $P[4] / P[8]$ are the pattern of mixed infections in this study.

The percentage of G1 P [8] was decreasing constantly from $70 \%$ in 2006 [20] to $19 \%$ in 2011 [40] and $2.2 \%$ in 2013 [19]. Epidemiological and molecular studies in many countries show complex patterns of change from 1 year to the next of Rotavirus serotypes associated with diarrhea from the same geographical areas [42].

The Rotavirus vaccination has not been incorporated in the national immunization schedule in Nepal. However, there are instances of immunization on the advice of clinician. Because of high burden of Rotavirus gastroenteritis the necessity of vaccination can be appreciated. The steep decrease in burden of diarrhea after implementation of vaccination program can be expected from the experience of countries like USA, Finland, Belgium, Brazil, Venezuela, Mexico where Rotavirus vaccination has been adopted. The reduction of all cause diarrhea hospitalizations is larger in less than 1 year old (35.6\%) compared to one to 4 year old children (12.3\%) as noted in the study by Gurgel et al. [43].

\section{Conclusion}

Rotavirus diarrhea is, mostly affecting children from 7 to 24 months in Nepal, mostly occurring in winter. The circulating genotypes in the country are found to be primarily unusual genotypes and predominance of G12P[6]. It is recommended to conduct genotyping of Rotavirus on large samples before starting vaccination in the country.

\section{Additional file}

Additional file 1: The data generated during the study. It includes the data generated like age/sex, month of hospital visit, number of diarrhea and vomiting in excel sheet. (XLSX $50 \mathrm{~kb}$ )

\section{Abbreviations}

$\mu$ l: Microliter; cDNA: Complementary DNA; DNA: Deoxyribonucleic Aicd; dNTP's: Deoxynucleotide triphosphate; dsRNA: Double stranded RNA;

ELISA: Enzyme Linked Immuno Sorbent Assay; IRB: Institutional Review board; $\mathrm{MgCl}_{2}$ : Magnesium Chloride; $\mathrm{mM}$ : Milli mole; PCR: Polymerase Chain Reaction; RNA: Ribonucleic Acid; RT-PCR: Reverse Transcriptase Polymerase Chain Reaction; RV: RotaVirus; TUTH: Tribhuvan University Teaching Hospital; VP: Viral Protein; WHO: World Health Organization

\section{Acknowledgements}

We thank Åshild K Andreassen, Basudha Shrestha, Shovita Shrestha for training on molecular biology techniques as well as primer selection including entire members of Department of Microbiology, IOM for their cooperation and guidance.

\section{Funding}

The necessary reagents and supplies were provided by Department of Microbiology, TUTH. The stationery requirements were arranged by corresponding author on own self.

\section{Availability of data and materials}

The dataset generated during the study are available in the data_diarrhea repository within the Additional file 1.

\section{Authors' contributions}

First Authors: $(A B)(F G) S D$ is primary and corresponding author who designed the study methodology, performed laboratory investigation and prepared the article for submission. (AB) (FG) HPK and BPR helped to design the study, helped in performing laboratory investigation, performed proof reading of article and made necessary arrangements of reagents. Second Authors: (ES) JBS, BMP, KP helped for-literature review, design the study, prepare the laboratory protocols and analyzing the impact of the study. (ES) (FG) SKM, SS, and NS are faculties of the Department who helped in designing the study, selecting primers, data entry, analysis and proof reading of article. (FG) SKhad, SKhat and NP are post graduate students in the department who helped during filling consent form, sample collection and extraction of nucleic acid and drafting the manuscript.

\section{Authors' information}

1. Subhash Dhital: M.Sc in Clinical Microbiology, Microbiologist, National Public Health Laboratory

2. Hari Prasad Kattel: M.Sc in Clinical Microbiology, Microbiologist/ Incharge, Department of Microbiology, TUTH

3. Basista Prasad Rijal: M. Phil, Ph. D Head of Department, Department of Microbiology, TUTH

4. Jeevan Bahadur Sherchand: Ph. D, Post Doc, Director, Department of Research. Professor, Department of Microbiology, TUTH.

5. Bharat Mani Pokharel: Ph. D, Post Doc, Assistant Dean, Institute of Medicine. Professor-Department of Microbiology, TUTH.

6. Keshab Parajuli: Ph. D. Professor, Department of Microbiology, TUTH. 
7. Niranjan Shah: M.Sc in Biotechnology. Assistant Professor Department of Microbiology, TUTH.

8. Shyam Kumar Mishra M.Sc in Clinical Microbiology, Assistant Professor Department of Microbiology, TUTH.

9. Sangita Sharma MD in Microbiology, Assistant Professor Department of Microbiology, TUTH.

10.Sundar Khadka M.Sc in Clinical Microbiology, Microbiologist, National Public Health Laboratory

11.Sulochana Khatiwada, M.Sc in Clinical Microbiology, Lecturer, Department of Microbiology, Universal college of Medical Sciences and Teaching Hospital.

12.Narayan Parajuli, M.Sc in Clinical Microbiology. Lecturer, Department of Microbiology, ManMohan Institute of Health Sciences.

\section{Competing interests}

The authors declare that they have no competing interests.

\section{Consent for publication}

Not applicable.

\section{Ethics approval and consent to participate}

The ethical approval for study was taken from Institutional Review board, Tribhuvan University Teaching Hospital, IOM before sample collection. The issued letter of IRB can be presented on request. The written consent was taken from parents/guardian of the infant or child in a local language preferably, or English when appropriate. All of the participants enrolled in this study had granted the consent.

\section{Publisher's Note}

Springer Nature remains neutral with regard to jurisdictional claims in published maps and institutional affiliations.

\section{Author details}

${ }^{1}$ National Public Health Laboratory, HIV Reference Unit, Kathmandu, Nepal. 2Department of Microbiology, Tribhuvan University Teaching Hospital, Kathmandu, Nepal. ${ }^{3}$ Department of Microbiology, Universal Medical College, Bhairahawa, Nepal. ${ }^{4}$ Department of Microbiology, ManMohan Memorial Institute of Health Sciences, Kathmandu, Nepal.

\section{Received: 24 March 2016 Accepted: 1 April 2017}

\section{Published online: 07 April 2017}

\section{References}

1. Estes MK. Rotavirus. In: Fields BN, Peter M, Diane E, Griffin RA, editors. Fields Virology. 5th ed. Philadelphia: Lippincott, Williams and Wilkins; 2007. p. 1917-74.

2. World Health Organization. Rotavirus vaccines. Wkly Epidemiol Rec. 2007:82:285-96

3. Parashar UD, Burton A, Lanata C, Boschi-Pinto C, Shibuya K, Steele D, et al. Global mortality associated with Rotavirus disease among children in 2004 J Infect Dis. 2009;200:9-15.

4. Jayaram H, Estes MK, Prasad BV. Emerging themes in rotavirus cell entry, genome organization, transcription and replication. Virus Res. 2004;101:67-81.

5. Clark HF, Offit PS, Glass RI, Ward RL. Rotavirus vaccines. In: Plotkin SA, Orenstein WA editors. Vaccines. 4th ed. Philadelphia: Saunders; 2004. p. 1327-45.

6. World Health Organisation. 2009. Fact sheet.

7. World Health Organization. Position Paper on Rotavirus Vaccines. 2013;88:49-64

8. Parashar UD, Johnson H, Steele AD, Tate JE. Health Impact of Rotavirus Vaccination in Developing Countries: Progress and Way Forward. Clin Infect Dis. 2016:62(suppl 2):S91-5.

9. Pun SB, Nakagomi T, Sherchand JB, Pandey BD, Cuevas LE, Cunliffe NA, et al. Detection of G12 human rotaviruses in Nepal. Emerg Infect Dis. 2007:13:482-4.

10. Pandey BD, Pun SB. Trends of Rotavirus in Nepal. KUMJ. 2011;9:32-5.

11. Pun SB. Rotavirus infection: An unrecognised disease in Nepal. KUMJ. 2010:8:135-40

12. Sherchand JB, Tandukar S, Sherchan JB, Rayamajhi A, Gurung B, Shrestha L, et al. Hospital-Based Study in Children with Rotavirus Gastroenteritis and Other Enteropathogens. J Nepal Health Res Counc. 2012;10:130-5.

13. Sherchand JB, Pandey BD, Nakagomi O, Nakagomi T, Yokoo M, Cunliffe NA. Molecular epidemiology of Rotavirus Diarrhea among children aged $<5$ years in Nepal: predominance of Emergent G 12 strains during 2 years. J Infect Dis. 2009:200:S182-7.

14. Bányai K, Bogdán A, Kisfali P, Molnár P, Mihály I, Melegh B, et al. Emergence of serotype G 12 rotaviruses. Hungary Emerg Infect Dis. 2007;13:916-9.

15. Tcheremenskaia O, Marucci G, De Petris S, Ruggeri FM, Dovecar D, Sternak SL, Matyasova I, Dhimolea MK, Mladenova Z, Fiore L, Rotavirus Study Group. Molecular epidemiology of rotavirus in Central and Southeastern Europe. J Clin Microbiol. 2007:45:2197-204.

16. Gouvea V, Glass RI, Woods P, Taniguchi K, Clarke HF, Forrester B, et al. Polymerase chain reaction amplification and typing of Rotavirus nucleic acid from stool specimens. J Clin Microbiol. 1990;28:276-82.

17. Iturriza-Gómara M, Kang G, Gray J. Rotavirus genotyping: keeping up with an evolving population of human rotaviruses. J Clin Virol. 2004:31:259-65.

18. Gentsch JR, Glass RI, Woods P, Gouvea V, Gorziglia M, Flores J, et al. Identification of group A Rotavirus gene 4 types by polymerase chain reaction. J Clin Microbiol. 1992;30:1365-73.

19. Ansari S, Sherchand JB, Rijal BP, Parajuli K, Mishra SK. Dahal RK, et a Characterization of Rotavirus causing acute diarrhea in children in Kathmandu, Nepal, showing the dominance of serotype G12. J Med Microbiol. 2013;62:114-20.

20. Uchida R, Pandey BD, Sherchand JB, Ahmed K, Yokoo M, Nakagomi T, et al. Molecular epidemiology of Rotavirus diarrhea among children and adults in Nepal: detection of G12 strains with P6 or P8 and a G11 P25 strains. J Clin Microbiol. 2006:44:3499-505

21. Kawai K, O'Brien MA, Goveia MG, Mast TC, El Khoury AC. Burden of Rotavirus gastroenteritis and distribution of Rotavirus strains in Asia a systematic review. Vaccine. 2012;30:1244-54

22. Odimayo MS, Olanrewaju WI, Omilabu SA, Adegboro B. Prevalence of Rotavirus induced diarrhea among children under 5 years in Ilorin. Nigeria J Trop Pediatr. 2008:54:343-6.

23. Saravanan $\mathrm{P}$, Ananthan $\mathrm{S}$, Ananthasubramanian M. Rotavirus infection among infants and young children in Chennai, South India. Indian J Med Microbiol. 2004;22:212-21.

24. Ahmed S, Kabir ARML, Rahman A, Hussain M, Khatoon S, Hannan A. Severity of Rotavirus diarrhea in children: one year experience in a children hospital of Bangladesh. Iran J Padiatr. 2009;19:108-16.

25. Zheng BJ, Ma GZ, Tam JSL, Lo SK, Ng MH, Lam BC, et al. The effects of maternal antibodies on neonatal Rotavirus infection. Pediatr Infect Dis J. 1991;10:865-8

26. Nakawesi JS, Wobudeya E, Ndeezi G, Mworozi EA, Tumwine JK. Prevalence and factors associated with rotavirus infection among children admitted with acute diarrhea in Uganda. BMC Pediatr. 2010;10(1):69.

27. Labaron CW, Lew J, Glass RI. Rotavirus study group annual Rotavirus epidemic patterns in North America. J Am Med Assoc. 1990;264:983-8.

28. Sherchan JB, Ohara H, Sherchand JB, Tandukar S, Sakurada S, Gurung B, et al. Molecular evidence based hospital acquired Rotavirus gastroenteritis in Nepal. Prime J Microbiol Res. 2011;1:16-21.

29. Sherchand JB, Cuncliffe NA, Tandukar S, Yookoo M, Pandey BD, Niraula P, Panta AR, Nakagomi O. Rotavirus disease burden and molecular epidemiology in children with acute diarrhoea age less than 5 years in Nepal. J Nepal Paediatr Soc. 2011;31:209-15.

30. Rahman M, Matthijnssens J, Yang X, Delbeke T, Arijs I, Taniguchi K, et al. Evolutionary history and global spread of the emerging G12 human rotaviruses. J Virol. 2007;81:2382-90.

31. Rahman M, Sultana R, Ahmed G, Nahar S, Hassan Z, Saiada F, et al. Prevalence of G2P[4] and G12P[6] Rotavirus, Bangladesh. Emerg Infect Dis. 2007:13:18-24.

32. Sharma S, Ray P, Gentsch JR, Glass Rl, Kalra V, Bhan MK. Emergence of G12 rotavirus strains in Delhi, India, in 2000 to 2007. J Clin Microbiol. 2008:46:1343-8.

33. Cunliffe NA, Dove W, Bunn JE, Ramadam MB, Nyangao JW, Riveron RL, et al. Expanding global distribution of rotavirus serotype G9: detection in Libya, Kenya, and Cuba. Emerg Infect Dis. 2001;7:890-2.

34. Clark HF, Lawley DA, Schaffer A, Patacsil JM, Marcello AE, Glass Rl, et al. Assessment of the epidemic potential of a new strain of rotavirus associated with the novel G9 serotype which caused an outbreak in the United States for the first time in the 1995-1996 season. J Clin Microbiol. 2004;42:1434-8.

35. Mullick S, Mukherjee A, Ghosh S, Pazhani GP, Sur D, Manna B, et al. Community based case-control study of rotavirus gastroenteritis among young children during 2008-2010 reveals vast genetic diversity and increased prevalence of G9 strains in Kolkata. PLoS One. 2014;9:e112970. 
36. Bányai K, Martella V, Jakab F, Melegh B, Szücs G. Sequencing and phylogenetic analysis of human genotype $P$ [6] rotavirus strains detected in Hungary provides evidence for genetic heterogeneity within the P [6] VP4 gene. J Clin Microbiol. 2004:42:4338-43.

37. Damanka S, Adiku TK, Armah GE, Rodrigues O, Donkor ES, Nortey D. Rotavirus infection in children with diarrhoea at Korle-Bu Teaching Hospital in Ghana. Jpn J Infect Dis. 2016;69(4):331-4.

38. Jain S, Thakur N, Vashistt J, Grover N, Krishnan T, Changotra H.

Predominance of unusual rotavirus G1P [6] strain in North India: An evidence from hospitalized children and adult diarrheal patients. Infect Genet Evol. 2016;46:65-70.

39. Esona MD, Armah GE, Steele AD. Rotavirus VP4 and VP7 genotypes circulating in Cameroon: identification of unusual types. J Infect Dis. 2010;202:S205-11

40. Santos N, Hoshino Y. Global distribution of Rotavirus serotypes/genotypes and its implication for the development and implimentation of an effective Rotavirus vaccine. Rev Med Virol. 2005;15:29-56.

41. Forster J, Guarino A, Parez N, Moraga F, Román E, Mory O, et al. Hospital-based surveillance to estimate the burden of Rotavirus gastroenteritis among European children younger than 5 years of age. Pediatrics. 2009;123:393-400.

42. Bishop RF, Masendycz PJ, Bugg H, Carlin JB, Barnes GL. Epidemiological patterns of rotaviruses causing severe gastroenteritis in young children throughout Australia from 1993 to 1996. J Clin Microbiol. 2001;39:1085-91.

43. Gurgel QR, Ilozue C, Correia JB, Centenari C, Oliveira SM, Cuevas LE. Impact of Rotavirus vaccination on diarrhoea mortality and hospital admissions in Brazil. Trop Med Int Health. 2011;16:1180-4.

\section{Submit your next manuscript to BioMed Central and we will help you at every step:}

- We accept pre-submission inquiries

- Our selector tool helps you to find the most relevant journal

- We provide round the clock customer support

- Convenient online submission

- Thorough peer review

- Inclusion in PubMed and all major indexing services

- Maximum visibility for your research

Submit your manuscript at www.biomedcentral.com/submit 